IRSH 64 (2019), pp. 5 I 5-53 I doi:I0.IOI7/S00208590I90004 Is

(C) 2019 Internationaal Instituut voor Sociale Geschiedenis

REVIEW ESSAY

\title{
The Rise of the European Migration Regime and Its Paradoxes (1945-2020)
}

\author{
LEO LUCASSEN \\ International Institute of Social History \\ Cruquiusweg 3I, IOI9 AT, Amsterdam \\ E-mail: leo.lucassen@iisg.nl
}

Chin, Rita. The Crisis of Multiculturalism in Europe: A History. Princeton University Press, Princeton, NJ [etc.] 2017. xiv, 363 pp. \$35.00. (Paper: \$22.95.)

Comte, Emmanuel. The History of the European Migration Regime. Germany's Strategic Hegemony. [Routledge Studies in Modern European History, vol. 47.] Routledge, New York [etc.] 20I8. 234 pp. Ill. £IO5.00. (E-book: £35.99.)

Jensen, Steven L.B. The Making of International Human Rights. The i96os, Decolonization, and the Reconstruction of Global Values. Cambridge University Press, Cambridge [etc.] 2016). xii, 3 I 3 pp. Ill. £70.99. (Paper: $£_{22.99 .)}$

\section{INTRODUCTION}

How can we explain the demise of the new postwar moral framework of antiracism and equality and the subsequent rise of integration pessimism in Western Europe in the I980s, a pessimism that led to the widely accepted idea, from left to right, that "multiculturalism" has failed? And how does this square with the simultaneous establishment of an extraordinary free migration regime within Europe that enables EU citizens to move and pick up work in any other member state? Answers to these questions can be found in three very different, yet complimentary studies that help us to understand more deeply the current alarmist public view of migration and integration, as well as its historical roots: The Crisis of Multiculturalism by Rita Chin, based in Ann Arbor; The European Migration Regime by Emmanuel Comte, 
from Berkeley; and Steven Jensen's (Danish Institute for Human Rights) The Making of International Human Rights. The studies by Chin and Comte offer a representative gauge of the blossoming field of migration studies and, in particular, show how this specialist niche can enrich insights into much broader (political, cultural, economic, and social) postwar developments in Europe and beyond. Jensen's innovative and critical book on the postwar "humanitarian turn" is highly relevant for migration studies, as it places the establishment of the United Nations (UN) and a number of its institutions, such as UNHCR and UNESCO, in a new light. Although many more books have been published on these topics in recent years, these three complement each other and provide a useful building block for a new understanding of the emergence of the postwar European migration regime, its paradoxes and consequences. In this review, I will first sketch the wider context and then detail the three books and how they relate to each other.

\section{THE ROOTS OF EUROPEAN MIGRATION REGIMES AND MULTICULTURALISM}

In order to understand the new perspectives of the three studies mentioned in the introduction, we need to zoom out and realize that, for centuries, migration, especially in Western Europe, was relatively free and primarily governed by labour market needs. ${ }^{\text {I }}$ State intervention was largely to stop people from leaving, because, from a mercantilist point of view, mercantilist rulers were afraid to lose workers, tax payers, and potential soldiers. ${ }^{2}$ Another motive to intervene was to stimulate or prohibit certain religious groups from entering, which explains the specific migration destinations of French Huguenots (Protestant states like Prussia and the Dutch Republic) and Iberian Jews (the Ottoman Empire and - again - the Dutch Republic). ${ }^{3}$ With the rise of nation states in the nineteenth century, somewhat paradoxically, this migration regime became even more open, as the freedom of movement fitted hand in glove with the dominating liberal laissez-faire ideology in the North Atlantic and beyond - at least, in so far as it concerned (Western) Europeans.

I. Leslie Moch, Moving Europeans: Migration in Western Europe since I650 (Bloomington, IN, 2003), and Klaus J. Bade, Pieter C. Emmer, Leo Lucassen and Jochen Oltmer (eds), The Encyclopedia of Migration and Minorities in Europe: From the I7th Century to the Present (New York, 20II).

2. Dorothee Schneider, "The United States Government and the Investigation of European Emigration in the Open Door Era", in Nancy L. Green and Francois Weil (eds), Citizenship and Those Who Leave: The Politics of Emigration and Repatriation (Urbana, IL [etc.], 2007), pp. 195-210, 197.

3. Geert Janssen, "The Republic of the Refugees: Early Modern Migrations and the Dutch Experience”, The Historical Journal 60:I (2017), pp. 233-252; Carolyn Chappell Lougee, Facing the Revocation: Huguenot Families, Faith, and the King's Will (Oxford, 2016). 
The movement of Asians and Africans was deemed problematic and unwanted, on the other hand, especially Chinese migrant workers, who were initially welcomed during the gold rush in California and Australia in the I 850 s, but were soon banned, leading to a global bifurcation that aimed at keeping Asians out of the North Atlantic and Western offshoots such as Australia. ${ }^{4}$ Only under certain restrictive (indentured) conditions and through colonial (British and Dutch) circuits were South and Southeast Asian workers transferred to the Caribbean and South Africa. The internal mobility of Africans, finally, was subject to colonial schemes and most left the continent through forced deportation to the Americas as enslaved workers. Partly due to British attempts to suppress the slave traffic, in the nineteenth century the centre of the trade shifted to the South Atlantic.'

For most Europeans other rules prevailed. In the long nineteenth century that ended in I9I 4, some 50 to 60 million left the continent freely to settle permanently or temporarily in the Americas, South Africa, and Oceania. Many others moved through colonial circuits to Asia and Africa, ${ }^{6}$ as bureaucrats, soldiers, sailors, missionaries, and merchants, many of them as "organizational migrants". ${ }^{7}$ An often overlooked group in this connection are Europeans who were moved against their will, such as convicts, to other parts of the world or otherwise sent to white settler colonies in the empire, as part of social engineering plans. ${ }^{8}$

And then there were millions who crossed national borders within Europe, such as Italian workers in France, Irish workers in the United Kingdom, and the Dutch in Germany. The spectacular development of industrial regions the British Midlands, the Ruhr area, and parts of (north-)eastern France, drew millions of internal and foreign labour migrants, who, in time, traded their nationality and added to the ethnic mixture of European nation states. ${ }^{9}$

4. Adam McKeown, Melancholy Order: Asian Migration and the Globalization of Borders (New York, 2008); Beth Lew-Williams, The Chinese Must Go: Violence, Exclusion and the Making of the Alien in America (Cambridge, MA, 2018).

5. Daniel B. Domingues da Silva, The Atlantic Slave Trade from West Central Africa, $1780-1867$ (Cambridge, 2017), p. 30.

6. Ulbe Bosma, "Sailing through Suez from the South: The Emergence of an Indies-Dutch Migration Circuit, I8I 5-1940”, International Migration Review 41:2 (2007), pp. 51 I-536; Valeska Huber, Channelling Mobilities: Migration and Globalisation in the Suez Canal Region and Beyond, I869-1914 (New York, 2007).

7. Leo Lucassen and Aniek X. Smit, "The Repugnant Other: Soldiers, Missionaries and Aid workers as Organizational Migrants", The Journal of World History $25: 4$ (2015), pp. I-39.

8. Christian de Vito and Alex Lichtenstein, "Writing a Global History of Convict Labour", International Review of Social History, 58:2 (2013), pp. 285-325; Clare Anderson (ed.), A Global History of Convicts and Penal Colonies (London, 2018); Ellen Boucher, Empire's Children: Child Emigration, Welfare, and the Decline of the British World, 1869-1967 (Cambridge, 20I4).

9. Leo Lucassen, The Immigrant Threat: The Integration of Old and New Migrants in Western Europe since I850 (Urbana, IL [etc.] 2005). 
The outbreak of World War I in I9I 4 signalled the end of the free migration regime in most parts of Europe and gave way to a more regulated system in which nation states started to distinguish between their "own" workers and foreigners, who could be refused entry to the national labour market in the interest of national workers. The main reason was the ingrowth of the state in society and the emergence of national welfare systems, no matter how embryonic. ${ }^{10}$ This process accelerated during World War I when organized labour found itself in a much more advantageous position due to the dearth of workers, who were fighting and dying in the trenches, or who were mobilized, as in the neutral Netherlands. The authorities wanted to avoid labour unrest at all costs, and after the October Revolution in I917 Russia the ruling elites were even more motivated to appease workers. The result was the establishment of universal suffrage and the introduction of national social welfare schemes. As a result states became more sensitive to protests of organized labour against what they saw as unfair competition by foreign workers. At the same time states realized that, with the emergence of social benefits at the national level, it was in their interest to put national workers first to avoid a situation in which they would pay their own workers unemployment benefits and allow foreign workers to take their place in the workforce. Hence the protection of national labour markets, the establishment of border guards, the spread of passports and identity papers and the registration of foreigners. ${ }^{\text {II }}$

Notwithstanding these institutional and political changes, labour migration within Europe, but also to South America, continued after I9 1 8, depending on the economic situation and the pull of labour markets. In a number of countries authorities and bureaucrats even expected the pre-war laissez-faire system to return. As soon as the economic crisis hit the global economy in 1929, however, it became clear that democracy and national welfare systems had wrought a permanent regime change. With the advent of mass unemployment, migration became increasingly restricted. Simultaneously, immigrants became the object of nativist resentment, foreshadowing fears about the unassimilable foreigners that form the core of Rita Chin's book on multiculturalism in postwar Europe. Such fears were in themselves not new, as the agitation against Irish, Chinese and Jewish immigrants in the USA in the nineteenth century shows,

ı. Marcel van der Linden, "The National Integration of European Working Classes ( I 87 I-I 9I 4): Exploring the Causal Configuration”, International Review of Social History 33:3 (I988), pp. $285-$ 3 I I; Leo Lucassen, "The Great War and the Origins of Migration Control in Western Europe and the United States (I880-1920)", in Anita Böcker et al. (eds), Regulation of Migration: International Experiences (Amsterdam, I998), pp. 45-72.

I I. Clifford Rosenberg, Policing Paris: The Origins of Modern Immigration Control Between the Wars (Ithaca, NY [etc.] 2006). See also John Torpey, The Invention of the Passport: Surveillance, Citizenship and the State (Cambridge, 2000), and Nancy L. Green and François Weil, eds. Citizenship and Those Who Leave: The Politics of Emigration and Expatriation (Urbana, IL [etc.], 2007). 
but now became part of the dominating state discourse. ${ }^{\mathrm{I2}}$ In Europe the first newcomers who were confronted with racist and culturalist stereotypes were colonial migrants, who arrived in considerable numbers during World War I, especially in France, but also during the interwar period. How this upset contemporaries, especially authorities, is revealed by Clifford Rosenberg in his insightful book Policing Paris, in which he shows how the Parisian police was obsessed with surveilling colonial residents, most of them from Algeria and West Africa. Although many were French citizens, their ethnic and cultural background were deemed a threat to the French nation and their presence hence highly problematic. This was also reflected in the work of the (then) well-known and respected demographer Georges Mauco, published in I932. His work was characterized by what he, and many others, saw as grave immigration problems and failing integration, not only of Algerians and Moroccans, but also of Poles and Italians. ${ }^{\text {I3 }}$

Another example of nativist inspired integration pessimism in the interwar period is the opposition to the reception of Jewish refugees from Germany in Western Europe. Soon the Netherlands, Belgium, France, and the UK raised objections, and from 1938 onwards legal barriers were raised, with the argument that Jews were a cultural threat, linked to their religion and alleged group character, which was often defined in racialized and antisemitic terms, thereby reproducing the Nazi ideology. ${ }^{14}$ In Eastern Europe, antisemitism was generally much more widely spread and Jews were seen as the ultimate Other, who could never belong to the nation. ${ }^{\text {Is }}$

\section{THE FORGING OF A NEW EUROPEAN MIGRATION REGIME}

With the defeat of Nazi Germany, a new migration regime evolved. If we look at the broader picture, this regime was the result of unanticipated developments, such as decolonization, the signing of the 195 I Refugee Convention and the unforeseen consequences of the welfare state and the ideology of equality ${ }^{16}$ which in the long run enabled the family reunification of guest workers from North Africa and Turkey. These three developments changed migration dynamics, as well as the discourse about migrants and their

I 2. Hidetaka Hirota, Expelling the Poor: Atlantic Seabord States $\mathcal{E}$ the I9th-Century Origins of American Immigration Policy (Oxford, 2017).

13. Georges Mauco, Les étrangers en France. Leur rôle dans l'activité économique (Paris, 1932). I4. Paul R. Bartrop, The Evian Conference of 1938 and the Jewish Refugee Crisis (London, 201 8); Michael Marrus and Robert O. Paxton, Vichy France and the Jeres (Stanford, I98 I), pp. 36-37. I 5. Theodore R. Weeks, From Assimilation to Antisemitism: The "Jewish Question" in Poland, I850-1914 (DeKalb, IL, 2006); Brian Porter, When Nationalism Began to Hate: Imagining Politics in Nineteenth-Century Poland (New York, 2000).

I6. Saskia Bonjour, "The Power and Morals of Policy Makers: Reassessing the Control Gap Debate”, International Migration Review, 45:I (20I I), pp. 89-I 22. 
settlement processes and, as such, constitute the foundation on which the analyses of Rita Chin, Emmanuel Comte, and Steven Jensen are based and form a useful background against which to evaluate their empirical and theoretical contributions. What all three developments have in common is that they separated migration from the labour market. Whereas, before the war, most migrants were drawn by the availability of jobs and higher wages, the Refugee Convention, decolonization, and the welfare/equality nexus, each in their own way, created different opportunity structures and hence migration dynamics.

\section{Decolonization}

Although, as Chin mentions, colonial migrants after World War II did react to labour market demands, as the cases of West Indians in the UK and Algerians in France show, a considerable numbers of migrants now left for political reasons, and not only because of the availability of employment and housing. The sudden and massive immigration of some 300,000 expatriates and (coloured) Eurasians from the former Dutch East Indies for example, in the late I940s and I950s, was deemed unwanted by the government at that time, and only by sheer luck largely coincided with the "trente glorieuses" that took off in 1952. ${ }^{17}$ By contrast, the exodus from Suriname just before Independence in I 975 , by descendants of former African slaves and Indian indentured workers, was badly timed, as their arrival coincided with a protracted economic recession. Similar mechanisms can be observed in other former colonial powers (UK, France, Portugal). ${ }^{18}$ The UK witnessed large arrivals from South Asia, East Africa, and the West Indies, with peak years in which many tried to beat the ban of restrictive immigration legislation (1962, 1968, and 1971). In France, the situation was somewhat different in that Algeria, until independence in 1962, was a French department and its inhabitants were French citizens free to move to the "hexagon", even after independence until I973.The population in the Domaines et Territoires d'Outre-Mer (DOM-TOM) found themselves in a similar situation and some 350,000 inhabitants from islands such as Guadeloupe, Martinique and Reunion used the opportunity to settle in France in the postwar period. ${ }^{19}$ In total some 8-9 million migrants from (former) colonies settled in Western Europe, most of them in France and

I7. Wim Willems, "No Sheltering Sky: Migrant Identities of Dutch Nationals from Indonesia”, in Andrea L. Smith (ed.), Europe's Invisible Migrants: Consequences of the Colonists' Return (Amsterdam, 2003), pp. 33-59.

I 8. Ulbe Bosma et al. (eds), Postcolonial Migrants and Identity Politics: Europe, Russia, Japan and the United States in Comparison (New York, 2012).

19. Peter Kivisto and Thomas Faist, Beyond a Border: The Causes and Consequences of Contemporary Immigration (Los Angeles, CA, 2010), p. 7 I. 
the UK, some 4 million each. ${ }^{20}$ Added to this number are the 2 million Russian "Aussiedler" in Germany, descendants of erstwhile German colonists who settled in Russia, arriving between 1989 and $200 \mathrm{I}$, and who can also be considered as "postcolonial”.

\section{Refugees}

The Geneva Refugee Convention of I95 I, initially limited to Europeans, was enacted in the mid-r950s and given global coverage in 1967. Until the r980s, however, it did not lead to large numbers of refugees from other continents coming to Europe. This changed at the end of the I980s with the Yugoslavian civil war, the simultaneous implosion of Eastern Europe and the military involvement of the United States and European allies in the Middle East and the Horn of Africa. ${ }^{2 I}$ The result was two periods of large inflows of asylum seekers in Western Europe (I990s and the years 2014$2017) .^{22}$ As with decolonization, political and humanitarian crises in source countries, mostly in Europe's southern and south-eastern rim (the Middle East and the Horn of Africa), were the prime movers, whereas labour market considerations played a minor role in people's motives for seeking asylum in Europe. Moreover, many of them first had to go through lengthy procedures during which they were not allowed to work and had problems certifying their diplomas.

\section{The welfare state and equality}

The third institutional factor that changed the (Western) European migration regime in the postwar period were the unintended and unforeseen effects of the welfare state, combined with a new normative framework that stressed the importance of equality, at least for the law. The effect on migration became particularly visible when in the mid-r970s Western European countries, which had until then recruited guest workers from southern Europe, North Africa and Turkey, decided to stop this scheme and close the borders for lowskilled labour migrants. Only then did non-European guest workers, in particular, realize that the legal and social rights they had built up would evaporate when they returned to their countries of birth. This affected both the social contributions for sickness, disability and unemployment they had paid, but also the acquired residence rights and the possibility to bring their families

20. Leo Lucassen, Jan Lucassen et al., Cross-Cultural Migration in Europe 190I-2000: A Preliminary Estimate. IISH Research Papers (Amsterdam, 20I4), pp. 39 and 46.

21. Aristide Zolberg, Astrid Suhrke et al., Escape from Violence: Conflict and the Refugee Crisis in the Developing World (Oxford, 1989).

22. Leo Lucassen, "Peeling an Onion: The 'Refugee Crisis' from a Historical Perspective”, Ethnic and Racial Studies, 4I:3 (2018), pp. 383-410. 
over. ${ }^{23}$ Both elements were the result of social pressures on European states by unions, who wanted to prevent unequal competition and wage reductions, and employers in whose interest it was to lengthen the stay of workers and who therefore opposed rotation systems. ${ }^{24}$ This was in sharp contrast to the position of Italians, and soon Greeks and Spaniards, who by then were free to move within the European Union and for whom returning did not lead to punishment, as they could re-enter whenever they wanted. ${ }^{25}$

When the recession set in in the early I 970 , however, there were also many Moroccan and Turkish guest workers in Western Europe who were recent arrivals, due to the high mobility. These workers had either not yet built up enough rights or had no legal status to start with, to which authorities had turned a blind eye as long as the demand for labour was high. Legally they could be deported, but civil society groups and politicians successfully argued that the principles of equality should be applied and that people in similar situations, although lacking legal documentation, had to be treated equally. As Saskia Bonjour has argued on the basis of the Dutch case, this ideology of equality evolved forcefully in the r 960 s as part of the international human rights turn, involving political-ethical norms, much more than legal regulations. It was politicians who first stressed the importance of "equal treatment", after which the courts followed. ${ }^{26}$

\section{The bumanitarian turn}

This emergence of a new normative framework and opportunity structure described by Bonjour fits well with what Steven L.B. Jensen has analysed in his book The Making of International Human Rights: The I960s, Decolonization, and the Reconstruction of Global Values, published in 2016. As part of a body of new critical studies on the history of the UN and other supra-national institutions after the war, he offers a very different picture than the self-congratulating linear story of the UN as the start of a diffused Western humanitarian regime formed as a reaction to the horrors of Nazism and fascism. In line with Mark Mazower's book No Enchanted Palace, ${ }^{27}$ Jensen shows how the UN initially was meant as a vehicle to promote and continue imperial interests, especially the British, in a neutral guise. The fact that the architect of South African Apartheid (officially enacted in 1948), Jan

23. On France, see also Chin, The Crisis of Multiculturalism, p. 8 I.

24. Ibid., p. 63.

25. Leo Lucassen and Jan Lucassen, Vijf eewwen migratie: Een verhaal van winnaars en verliezers (Amsterdam, 2018).

26. Saskia Bonjour, Grens en gezin. Beleidsvorming inzake gezinsmigratie in Nederland, I9552005 (Amsterdam, 2009), pp. I40-I4I.

27. Mark Mazower, No Enchanted Palace: The End of Empire and the Ideological Origins of the

United Nations (Princeton, NJ, 2009). 
Smuts, was one of the driving forces behind the UN and helped draft its Preamble, testifies to that. ${ }^{28}$

As Jensen stresses, however, during the negotiations of the Universal Declaration, published in 1948, others intervened and introduced issues and rights that soon transcended purely imperial-diplomatic interests, such as the universal right to social justice. More generally, Jensen argues, universality became the central notion, and ten days before its adoption in December 1948 the "International Declaration" changed to the "Universal Declaration". For the moral underpinnings of the postwar migration regime it was crucial that in 1947 the declaration in the making came under fire from the American Anthropological Association (AAA) for its colonial subtext; the AAA took a clear anti-racist position and rejected the biological frame to define and understand people from different cultures. ${ }^{29}$ The issue of racism remained an important theme and became a hot topic in the General Assembly at the end of the I940s, with communist states criticizing South Africa for its Apartheid legislation and the USA for discriminating against its own black citizens. The real breakthrough, however, as Jensen shows, was the pressure exerted by 29 independent Asian and African nations at the famous Bandung Conference in April 1955, among whom were India, China, Indonesia, Iran, Ethiopia, Egypt and Liberia. These countries were soon joined in the UN by a fast-growing number of decolonized African and Asian nations. This growing block condemned imperialism and colonialism and made anti-racism a cornerstone of the international order. ${ }^{3 \circ}$

\section{Non-European workers and multiculturalism}

The broad canvas sketched above is essential for understanding the interesting and well-written reconstruction by Rita Chin of the way France, Germany and the UK (and also Switzerland and the Netherlands) dealt with the social and cultural impact of non-European newcomers in their societies. Central to her analysis is the controversial term "multiculturalism". Chin is fully aware of the ambiguity this term carries and uses it in two different ways: firstly as an overarching ("an sich") concept to describe the settlement of non-Europeans in Western Europe since the late I940s and the way nation states dealt with this demographic change, whether the term "multiculturalism" was used or not at the time. Secondly, "multiculturalism" is analysed as a dominant discourse (a term "für sich") that became popular from the I980s and was used by politicians and others to refer either to the actual presence of non-European immigrants or to policies devised to accommodate their

28. Jensen, The Making of International Human Rights, p. 28.

29. Ibid., p. 3 I.

30. Ibid., pp. 59 and 106-107. 
presence. In her book, she gives a good overview of the major immigrant groups from Africa and Asia, starting with postcolonial newcomers in the UK, France, and the Netherlands in the I950s and I960s, how they were received and how the native population and politicians reacted to this unexpected change in their societies. Furthermore, she shows how guest workers from North Africa and Turkey added to the numbers of non-Europeans. In line with the historiography on this topic, Chin notes that until the I980s there was a relatively "open situation" and a moderate optimism about this "radical demographic transformation". ${ }^{31}$

This is primarily explained by the great demand for labour, which was partly met by workers from other continents, often through (former) imperial circuits. Moreover, the atrocities of the racist Nazi regime had produced a shock wave that discredited pre-war notions of race and heredity, as analysed in Jensen's study. Receiving countries started thinking about new ways to deal with the increasing ethnic diversity of their populations and the tensions that arose between the native population and the coloured newcomers. On occasion, blatant racism was openly expressed, especially among the working classes, and in 1958 widespread violence against West Indians erupted in Notting Hill in London. Three years later, on 17 October, a much more serious incident occurred in Paris, where the police suppressed a peaceful demonstration of Algerians, with forty acknowledged deaths, and estimates that run from one hundred to three hundred. Although this extremely violent reaction was part of a more general pattern of police brutality against (migrant) workers, ${ }^{32}$ it also expressed the deeply rooted racism in French society against Algerian immigrants. ${ }^{33}$

Notwithstanding these native backlashes, the reaction of mainstream politicians and civil society remained welcoming during the "trente glorieuses". Chin shows how, in all cases, the principle of non-discrimination and antiracism initially dominated, if only in the discourse, while the categories chosen ("race" in the UK, "foreigner" in Germany, "immigrant" in France, and "ethnic minority" in the Netherlands) differed. At the same time, however, these countries tried to restrict immigration from Asia and Africa through legislation, with the argument that integration policies could only work when numbers remained limited. Interestingly, this argument was not expressed in public, "front stage" to use Goffman's image, ${ }^{34}$ because politicians and

3I. How "radical” this was depends on one's subjective appreciation. In most Western European countries, the share of non-European immigrants did not go beyond ten per cent of the total population.

32. Jacob Paskins, Paris Under Construction: Building Sites and Urban Transformation in the I 960 (New York [etc.] 2016), p. 78. See also Neil MacMaster, Colonial Migrants and Racism. Algerians in France, 1900-62 (Houndmills, 1997), p. 20.

33. Lucassen, The Immigrant Threat, pp. I $84-185$.

34. Ervin Goffman, The Presentation of Self in Everyday Life (New York [etc.], 1959). 
bureaucrats were afraid that this would stimulate xenophobia and racism. The few politicians who in this period openly tried to mobilize anti-immigrant sentiments, like Enoch Powell in the UK in 1968, and Jean-Marie Le Pen in the early I970s in France, demonstrated the political potential of nativism, but at the same time were severely limited in their success by the prevailing anti-racist discourse, or, to use Chin's terms, the positive interpretation of multiculturalism. Furthermore, but this is not touched upon in her book, such resentments were voiced within existing political structures, but remained largely invisible. A good example is the French Communist Party, whose working-class following harboured anti-immigrant feelings that were not expressed by the party leadership and which remained subordinate to the larger class struggle. ${ }^{35}$

In this first phase of what we could call integration optimism, ${ }^{36}$ some sort of multiculturalist policy was formulated, which in the UK, France, and the Netherlands boiled down to involving organizations of migrants at the local level in policymaking and to accommodating certain religious and cultural expressions and needs. This approach is well captured in François Mitterrand's "droit à la différence", but should mainly be seen as a policy of containment and social control, as Chin rightly argues. ${ }^{37}$ Contrary to what critical authors such as David Goodhart in the UK have suggested, ${ }^{38}$ only a very light version of multiculturalism came about, which clearly stipulated that migrants had to obey the prevailing laws and were expected to integrate in the long run. ${ }^{39}$

The initial, largely symbolic, "multicultural" stance changed abruptly after the Rushdie affair (1988/89). No matter the clear caesura in I989, Chin rightly remarks that in the UK the pessimistic turn was preceded by the explicit nativist position taken by Margaret Thatcher, who came to power in 1979. Although at the local level moderate multiculturalist policies were continued, especially by Ken Livingstone in the Greater London Council, at the national level the discourse changed sharply and echoed Powell's alarming and racist anti-immigration discourse, with the criminality of West Indians as a focus point.

When Muslim migrants took to the streets in various Western European cities to protest against Salman Rushdie's novel The Satanic Verses, however, the

35. As vividly described in the autobiographic book Retour à Reims. Une théorie du sujet (Paris, 2009) by Didier Eribon.

36. Leo Lucassen and Jan Lucassen, "The Strange Death of Dutch Tolerance: The Timing and Nature of the Pessimist Turn in the Dutch Migration Debate", The Journal of Modern History, 87:I (20I5), pp. 72-IOI.

37. Chin, The Crisis of Multiculturalism in Europe, pp. I 17-1 23.

38. David Goodhart, The British Dream: Successes and Failures of Post-war Immigration (London, 2013). For the Netherlands, see Paul Scheffer, Immigrant Nations (Cambridge, 20I I). 39. See also Lucassen and Lucassen, "The Strange Death of Dutch Tolerance". 
mood changed fundamentally and this marks the beginning of perceiving and talking about immigration predominantly in terms of religion, or more specifically "Muslims". Chin does a good job in showing how, in various countries, Islam became the new rallying point, and how polarized discussions about religious symbols such as the veil (especially in France) developed into a clash of civilizations framework in which Muslims were collectively juxtaposed with "European values", with an interesting roll call of secular female migrants from Islamic countries, such as Hirsi Ali (Netherlands), Fadela Amara (France), and Necla Kelek (Germany), who were framed as "powerful exceptions that proved the rule of Islam's incompatibility with European norms". ${ }^{40}$ Conservative and extreme right-wing politicians (often) opportunistically and strategically embraced liberal values, such as women's and gay rights, as it supported their idea that multiculturalism had failed and parallel societies were on the rise, which was expressed in various ways by Sarkozy, Merkel, and Cameron.

Chin's comparative analysis of the shifting discourse is fascinating and rich, but also has some shortcomings. Firstly, she only very briefly touches on the influence of prominent American conservative thinkers such as Bernard Lewis and Samuel Huntington, or trendsetting European politicians such as the Dutch leader of the liberal party, Frits Bolkestein. ${ }^{4 \mathrm{I}}$ As others have shown, the framing of Muslim migrants as fundamentally opposed to "Western values" within a larger "clash of civilizations" deserves a more rigorous transnational analysis, which will show how, from the I990s, a transatlantic antiimmigrant and anti-Islam discourse developed, long before $9 /$ I I. $^{42}$ Since 2015 , with the "refugee crisis" and the election of Donald Trump as president of the United States, this convergence of integration pessimism reached a new phase with the emergence of a global extreme-right (alt-right) ideology that is shared through social media and internet sites in North America, Europe, and white settler colonies including Australia and New Zealand, as attested by the terrorist attacks at mosques in Christchurch on Is March 2019, by an Australian terrorist who was inspired by global white supremacist ideas and his travels in Europe.

Furthermore, Chin has chosen not to deal with the actual intergenerational integration. In itself this is legitimate, given the central discussion of her book, but some attention to the actual settlement process of migrants and their descendants would have helped to put the positive and negative discourse on multiculturalism in perspective and raised a number of additional highly interesting questions. For example, why has integration pessimism deepened (and

40. Chin, The Crisis of Multiculturalism in Europe, p. 228.

4I. Ibid., p. 273 and endnote ro2 on pp. 342-343.

42. Merijn Oudenampsen, "The Conservative Embrace of Progressive Values" (Ph.D., Tilburg University, 2018), published as De conservatieve revolte. Een ideeëngeschiedenis van de Fortuyn-opstand (Nijmegen, 2019). 
radicalized) in the last decade while integration in most countries continues? ${ }^{43}$ Ample studies show that the children and grandchildren of migrants are doing much better than one would assume on the basis of the critique of "multiculturalism" and that the idea of parallel societies is hugely exaggerated. ${ }^{44}$

Finally, she could have bolstered her argument by paying attention to the wider political-economic shifts that explain the rise of integration pessimism from the 1980 os onwards. The neo-liberal turn in particular and the accompanying rise of social inequality form a crucial breeding ground for right-wing, xenophobic, anti-migration rhetoric. ${ }^{45}$ By choosing for the Third Way in the I990s, social democrats widely embraced neo-liberalism and downgraded the welfare state, while right-wing populism seized the opportunity to frame immigrants and their children as the cause of social problems.

\section{European workers and freedom of movement}

Where Chin focuses on the reception of migrants from other continents in Western Europe, Emmanuel Comte concentrates on the changing migration regime within Europe. His book The History of the European Migration Regime is a systematic and thorough account of the emergence of a unique free migration space within Europe. He shows how Germany (and not Italy as many other scholars have claimed) played a deciding role in forging the gradual freedom of labour migration within the European Community (and finally the EU), stressing that this was far from a linear process with a clear plan in mind. This process started as early as the I950s when Germany, but also other Western European countries, experienced shortages of labour that could not be solved by the availability of colonial migrants. Apart from economic interests, Germany also had (geo)political reasons for urging such policies, since it would damage its reputation as representative of the West if it could not accommodate large numbers of refugees from Eastern Europe. It therefore needed other community members as a safety valve in case criticism emerged. Freedom of migration within the European Community offered a possible way out, in case the demand for labour in Germany was insufficient.

43. With white genocidal conspiracy ideas on the "replacement of the white European population" by (Muslim) immigrants from Asia and Africa, as argued by Renaud Camus in his Le Grand Replacement (Neuilly-sur-Seine, 20II), expressed by extreme right politicians in Germany (AfD), Austria (FPÖ), Belgium (Vlaams Belang) and the Netherlands (Thierry Baudet and Geert Wilders). Interestingly Marine le Pen, leader of the Front National in France, is distancing herself from such radical ideas (and thereby from her father and founder of the FN). 44. See e.g. Lucassen, The Immigrant Threat, and Maurice Crul and John Mollenkopf (eds), The Changing Face of World Cities: Young Adult Children of Immigrants in Europe and the United States (New York, 2012). For the USA, see also Nancy Foner, From Ellis Island to JFK: New York's Two Great Waves of Immigration (New Haven, CT, 2000).

45. Nancy Foner, Patrick Simon (eds), Fear, Anxiety, and National Identity: Immigration and Belonging in North America and Western Europe (New York, 201 5 ). 
Comte's meticulous analysis of the national and European sources in the period 1947-1992 shows that the gradual extension of the freedom to move within the European Community was the outcome of constant negotiations between member states, but foremost between Germany and France. The latter country's labour market was less in need of foreign labour due to the ample supply of colonial workers, especially from Algeria, and, moreover, the unions put up strong opposition. Only by giving in to France's demands in other fields, such as agricultural subsidies and development aid for French DOM-TOM areas, was Germany able to forge a more open internal migration regime in the I960s.

Comte's study therefore makes clear that the current internal freedom of labour migration within the EU did not originate with the Treaty of Maastricht (1992), but goes back to the very beginning of the European project and was a slow and tortuous process of reconciling different national social, economic, demographic, and political interests. A key event was the Treaty of Rome in 1957, after which a new European migration regime developed, yet with important exclusionary consequences for migrants outside the EU, as Comte reminds us. Restrictions were imposed on migrants from outside the European Community from the I960s, beginning with new legislation by former imperial powers. The best examples, also dealt with in Chin's book, are the 1968 Commonwealth Immigrants Act and the 197I Immigration Act, which limited the access to what was defined as "patrials", roughly speaking descendants of English born emigrants, thus excluding the bulk of the population in the former colonies. ${ }^{46}$

This ethnocentric definition was then adopted by other member states in the accession process of the UK in 1972 , resulting in limiting the freedom to migration within the European Community to patrials. This example shows how the discussion about internal (freedom of) migration was inextricably bound up with the exclusion of migrants from outside the common area, especially from former colonies, and actually made migrants second-rate European citizens in the UK. The same was true for West African and Maghreb migrants, who were allowed to enter France, but who - according to a Council decision in 1972 - could not move freely to other Community member states. Moreover, labour migration from other regions (especially North Africa and Turkey) came to a halt with the Oil Crisis in 1973, with European countries promoting the return of guest workers to Arab, African, and Middle Eastern countries.

The broader (discursive) context of this attempt to exclude non-Europeans is given in Chin's book, which analyses the increasing opposition to the changing ethnic demography of Western European nation states. Interestingly, parallel to this exclusion is the inclusion of Mediterranean countries in the 
emerging free European migration regime, including between and from "new" member states such as Greece, Spain, and Portugal. This extension went along with the gradual abolishment of internal border checks and the Schengen system, signed in June 1985 and enacted ten years later, extending the agreement that had already existed within the Benelux to France and Germany, with other EU states (except the UK). According to Comte, the further relaxation of internal borders should not simply be seen as a logical sequence to earlier decisions enabling the freedom of migration within the European Community but was the by-product of the wish of France and Germany to establish a single market, projected in 1992. For this reason, in the mid-1980s, President Mitterrand and his advisors, in contrast to the UK, decided to go along with opening the internal borders, favoured by Germany. ${ }^{47}$ The emergence of the new postwar European migration regime can therefore only be understood within the broader history of European unification; and neither development was a straightforward or intentional process.

Finally, Comte's careful and innovative reconstruction puts these postwar European developments into global perspective. This is best illustrated by the fact that the restrictive turn towards migrants from Asia and Africa in the 1970 s met with international protest in the UN by the countries of emigration and other UN members from the Global South. This links Comte's narrative to the broader canvas painted in Jensen's book. Thus, Comte explains how, in 1979, in a reaction to growing tensions in sending countries in Africa and the Near East in reaction to European immigration restrictions, the General Assembly formed a working group to study measures "to improve the situation and to enforce human rights and dignity of all migrant workers". Against the advice of the European Commission, it recommended that some sort of family reunification should be allowed. It comes as no surprise that, by the time the draft Convention was finalized in 1990, Western European states refused to ratify it. ${ }^{48}$ Nor is it surprising that the 1992 Treaty of Maastricht signalled the gradual building up of what has become known as "Fortress Europe", the full consequences of which only became fully clear during the "Refugee Crisis" of 2015, when hundreds of thousands of asylum seekers found themselves forced to take very risky routes across the Mediterranean. ${ }^{49}$

\section{CONCLUSION}

The emergence of the postwar migration regime in Europe confronts us with a number of paradoxes. On the one hand, it furthers the freedom of migration

47. Ibid., pp. I47-1 48 .

48. Ibid., p. I4 I.

49. Lucassen, "Peeling an Onion", pp. 383-410. 
within the EU, while at the same time it limits people from other continents coming in. Whereas internal migration is praised as the highlight of efficient labour market allocation and the expression of personal freedom - to work, study, and gain new experiences - this is denied to those outside the EU. Where human rights are praised as the heart of the European "value community", these rights are eroded daily by highly questionable deals with authoritarian regimes in Asia and Africa, with the aim to stop people from moving in the direction of Europe. Finally, there is the paradox of the creation of a global institutionalized, humanitarian, anti-discrimination framework, embodied in the UN and its institutions, and nativist and xenophobic discourses that legitimize exclusion and discrimination. To understand these paradoxes and their historical embeddedness, the new studies by Jensen, Chin, and Comte are most insightful. Although arising from very different directions and scholarly fields, they complement each other perfectly and help us to understand how, after World War II, a new European migration regime emerged. It created a new framework for regulating (labour) migration and furthermore defines the political and moral parameters for dealing with ethnic diversity in Europe. The studies discussed above also show that this regime is constantly in flux, with alternating periods of what can be called integration optimism and pessimism, which roughly coincide with changes in the "moral regime". Chin's study in particular shows how the postwar humanitarian turn, as described by Jensen, slowly gave way to a much more nativist, xenophobic, and Islamophobic atmosphere in the political and public sphere. This is part of a much broader return of conservative values and ideas, expressed in a revaluation of colonialism and the downplaying of slavery, as advocated by prominent historians such as Nigel Biggar, Niall Ferguson, Bruce Gilley, and others. ${ }^{50}$ Migration, obviously, is one of the domains in which this cultural battle is waged, both in academia and in society at large.

Historians of migration, and of human rights more broadly, will undoubtedly be inspired by the books discussed in this review article and may want to further develop the arguments and insights by global comparisons beyond Europe and with earlier periods. With regard to xenophobia and racism, an approach that is more longue durée would be most welcome. How unprecedented, for example, is the postwar business cycle of integration optimism and pessimism and does the immigration of non-Europeans constitute a new era, with different rules? Nancy Foner, who compared widespread (European) immigration to New York at the end of the nineteenth century with the much more global wave from the ig6os onwards, points at many

50. Pepijn Brandon and Aditya Sarkar, "Labour History and the Case against Colonialism", International Review of Social History, 64:I (2019), pp. 783-109; available at https://doi.org/10. I017/S0020859019000063; last accessed 3 June 2019. 
similarities, and the same is true for my own work on Western Europe. ${ }^{5 \mathrm{I}}$ One of the key questions, then, could be whether it really matters where migrants come from if we want to understand nativist and xenophobic reactions over time. And whether privileging migrants from Africa and Asia to Europe and North America as objects of study may unintentionally reproduce current xenophobic and racist convictions and attitudes. To avoid such consequences, comparisons in time and space are essential. They allow us to break away from the self-imposed North Atlantic chains and start systematically comparing attitudes to migrants worldwide.

5. Foner, From Ellis Island to JFK; Lucassen, The Immigrant Threat. 